\title{
Family Business and Financial Performance: What are the Effects of Tax Cut Policy on Them in Uzbekistan?
}

\author{
${ }^{1}$ Yusupov Jasurbek, ${ }^{2}$ Sakata Kei \\ ${ }^{1}$ The State Tax Committee of Uzbekistan, Tashkent, Uzbekistan \\ ${ }^{2}$ Former School of Economics, Ritsumeikan University, Shiga, Japan
}

\begin{abstract}
This study is the first comprehensive empirical study to examine the relationship between the family business and the firm's performance in Uzbekistan. In this research, we investigate the relationship between family firms and financial performance using enough extensive unbalanced panel data from 2012 through 2015 on 3148 non-banking/nongovernment firms. Moreover, we analyze the impact of tax cut policy on SMEs, including family firms from a case study of Uzbekistan by using the difference-in-difference estimator. These two will be a major contribution to the family business study field in Uzbekistan.
\end{abstract}

The results show that family businesses have on average 2.02 per cent higher return on assets than non-family firms. In the term of return on equity, they show 3.11 per cent higher performance compared to their counterparts. We found a small difference in net profit margin. Family firms have a 0.83 per cent higher indicator compared to non-family firms. Interestingly, our difference-in-differences estimates do not show any impact of tax cut on SMEs in a shortrun.

Overall, our results show outperformance of family businesses in comparison to their counterparts and suggest that family firms are efficient organizational structure.

Keywords: Family business, family firm, financial performance, Tax cut policy effect, SMEs

\section{Introduction}

A family business is the most common in the world, and it relies on a centuries-old traditional form of entrepreneurial activity. Family firms in countries with developed market economies are the basis for societal development, and they account for a significant portion of goods and services.

The research on the family business grew in popularity over the past two decades, and many researchers try to cover all aspects of this form of business. Calder (1953) examines the management problems of a small family-controlled manufacturing business. Despite many existing articles concerning the family business, this research is mainly motivated by Ronald C. Anderson's and David M. Reeb's research titled "Founding-Family Ownership and Firm Performance: Evidence from S\&P 500" in 2003 (Anderson \& Reeb, 2003). Because this article is one of the most-cited research papers in the study of the family business, it initiated the new era of family ownership and performance relationships. The relationship between family ownership/control/management and performance has become the focus of interest among family business researchers around the world. (e.g., Beehr, Drexler Jr., \& Faulkner, 1997;Ang, Cole, \& Lin, 2000; Habbershon, Williams, \& MacMillan, 2003;Anderson, Mansi, \& Reeb, 2003; Anderson \& Reeb, 2003;Miller, Le Breton-Miller, Lester, \& Cannella, 2007; Saito, 2008; Wong, Chang, \& Chen, 2010; Singal \& Singal, 2011; Garcia-Castro \& Aguilera, 2014; De Massis, 
Kotlar, Campopiano, \& Cassia, 2015; Gill \& Kaur, 2015). In their papers, the authors mostly found a positive relationship between family-owned firms and their performances.

Despite such findings that show a positive correlation between family businesses and their performance, some authors argue that family firms do not always differ from their counterparts in terms of financial performance. Westhead and Cowling (1997) claim that most studies have focused on the characteristics and performances of quoted companies listed on the stock exchange rather than independent unquoted companies. The reason why the analysis of listed companies cannot provide a clear picture of the family business and its performance could be explained by the size of the quoted firms in the stock market. Listed companies are usually formed as large companies; therefore, researching quoted firms may leave behind family firms organized as SMEs. Moreover, the critique of previous studies relates to the lack of consensus surrounding the definition of a family firm and disregarding of a broad range of financial performance indicators. Even a better non-family firm's financial performance in terms of growth in sales revenue, productivity and profitability were found by Binder Hamlyn (1994) using 667 unquoted private companies in the UK.

\section{Theoretical Background}

\subsection{Previous Studies}

Many types of research have been done worldwide regarding the family business and its impact on a firm's performance (e.g., Beehr, Drexler Jr., \& Faulkner, 1997; Ang, Cole, \& Lin, 2000; Habbershon, Williams, \& MacMillan, 2003; Anderson, Mansi, \& Reeb, 2003; Anderson \& Reeb, 2003; Miller, Le Breton-Miller, Lester, \& Cannella, 2007; Saito, 2008; Wong, Chang, \& Chen, 2010; Singal \& Singal, 2011; Garcia-Castro \& Aguilera, 2014; De Massis, Kotlar, Campopiano, \& Cassia, 2015; Gill \& Kaur, 2015). Nevertheless, Faccio et al. (2001) argue that its influence differs among countries and continents. They report that family ownership in East Asia leads to severe conflicts with other claimants and hampers firm performance. Therefore, this subsection provides a review of some studies which have been done in different countries on various continents.

In the U.S., Anderson and Reeb (2003) examine whether there is a relationship between founding-family ownership and firm performance in large public firms. The key findings of the research show that family ownership is prevalent in S\&P 500 companies, and these family firms perform better than non-family firms. Moreover, a U-shaped relationship between family ownership and firm performance is found, meaning that when family members are appointed as CEO, they perform better than when they are not in such positions. Their findings reinforce that of Faccio et al. (2001) concerning the role of a political-regulatory environment where family ownership in public firms reduces agency problems.

Martínez et al. (2007) 's study of South America's family-controlled firms listed on the stock market in Chile presents a more substantial financial performance than non-family firms in the long run. By using a set of data on Chilean companies from a sample of 175 firms listed on the stock market, they found that the group of hundred family-controlled firms performed significantly better than the group of seventy-five non-family companies over ten years (19952004). They used three distinct measures of performance. ROA, ROE and a proxy of Tobin's $Q$ were employed to test the differences in means between two groups of firms. As an implication of the research, the authors suggest that family firms under the pressure of "public market conditions" can behave as efficient performers. They also highlight that the great majority of family firms throughout the world do not operate under such conditions because they are privately owned companies, and many of them are "below-average" performers.

Bouzgarrou and Navatte (2013) found that family-controlled firms outperform non-family firms. Furthermore, they propose that the relationship between the family firm and performance relies 
on the control level. The higher operating performance of the family firm is statistically significant for an intermediate level of control. Cucculelli and Micucci (2008) investigated the impact of the founding chief executive officer succession on a sample of Italian firms. They found that inherited management within a family negatively affected the firm's performance, and the decrease was concentrated among good performing companies.

Furthermore, founder-run companies outperformed the average sectoral profitability better before the succession. Che and Langli (2015) by conducting various regression analyses of firm performance to ownership and board structure in Norwegian private family firms, finds that firm performance for firms with family ownership between $50 \%$ and $67 \%$ and of $100 \%$ is higher than family ownership in between-hence, they found a U-shaped relationship between family ownership and firm performance. Moreover, they suggest that the ownership of the second largest owner, the percentage of board members from the ruling family, and durable family power are positively related to firm performance.

Few studies are examining the relationship between the family business and the firm's performance in the Asian countries. In the Japanese example, Saito (2008) uses data from 1,818 publicly traded firms from 1990 to 1998 and finds that the founding families are a common and important class of shareholders and senior managers in Japan. Also, he finds that the performance of family firms both owned and run by the founder's heirs is inferior to that of nonfamily firms, but the performance of family firms owned or run by the founder's descendants is superior to that of non-family firms. The author proposes that this result may indicate that the founders add firm value through their valuable skills, and poor performance of descendant firms is mainly the result of governance problems between large and small shareholders. Gill and Kaur (2015) discern the relationship between family involvement in business and financial performance of companies listed in the S\&P BSE 500 Index during the period 2006-2010 in India. The authors controlled for company-specifics, industry affiliations, and corporate governance variables. Furthermore, the cross-sectional longitudinal analyses show that family business is associated with superior financial performance, and financial performance is higher for family firms than non-family firms. Moreover, based on the market performance measure, the family firm appears to be a better performer with higher outside board representations.

Even though there is a significant impact of research mentioned above on modern family business, some similarities and approaches undertaken had lead to critiques. Firstly, almost all scholars concentrated on examining companies listed on the stock market, which are mostly large. As a result, many family firms in the form of SMEs were left out. Second, most of them use the same financial performance indicators like "return on assets" or "Tobin's q" instead of trying to use other various indicators.

\section{Empirical Analysis}

\subsection{An Empirical Model, Variable Selection and Description}

A multivariate analysis examines the family business and firm performance relationship, including a random effects panel model. Because our main variable of interest regarding a family business is not continuous, we will use a random-effects panel data regression model. The regression equation employed for the analysis is:

$y_{i t}=\gamma$ family $_{i t}+X \beta+u_{i t}$

where $u_{i t}=\alpha_{i}+\varepsilon_{i t}$.

$y_{i t}$ denotes the performance of a firm such as ROA, NPM and ROE.

$X$ is a vector of the other control variables. $X$ includes Investment Ratio, FLR, SIZE, AGE, SECDUM, YEARDUM, URBDUM.

$u_{i t}$ contains $\alpha_{i}$ which is an individual random effect, and $\varepsilon_{i t}$ follows iid. 
All variables used in this model will be described below:

Measures of Financial Performance. In previous literature, scholars used two dimensions of financial performance: an accounting-based measure and a market-based measure. In the account-based measure, they widely used the coefficient return on assets (ROA), and in a market-based measure, the coefficient is Tobin's Q. In our case, due to an underdeveloped stock market in Uzbekistan, the sample does not contain listed companies, which leads us to use an accounting-based measure of financial performance only. However, along with ROA, we will use other financial performance indicators like ROE (Return on Equity), and NPM (Net Profit Margin) which widely show different aspects of profitability for the companies. These indicators will be described as follows:

1. Return on Assets $(R O A)$ : a financial ratio characterizing the return on the use of all assets in the firm. This coefficient shows the company's ability to generate profit without taking into account the structure of its capital (financial leverage), the quality of asset management. Return on assets is calculated by dividing the net profit by the value of all assets:

Return on Assets $=$ Net Income $/$ Assets

2. Return on Equity (ROE): a scale of net profit in comparison with the firm's equity. ROE is the most important financial indicator of return for any investor or the business owner, showing how effectively the capital invested in the business was used. Unlike similar indicators such as "return on assets", this indicator characterizes the efficiency of not using the entire company's capital, but only that part pertaining to company owners. To calculate return on equity, we will divide the net profit by the company's equity:

Return on equity $=$ Net income / Equity

3. Net Profit Margin (NPM): an indicator of the financial performance of the company, showing what part of the revenue company capitalizes from. Profit margin is indicated as a percentage and, in effect, measures how much out of every monetary unit the sales a company keeps in earnings.

Net Profit Margin= Net Profit / Revenue

The Measure of a Family Business. As noted in the previous chapter, the family business was defined following three main approaches according to their characteristics: the involvement approach, the intention-based approach, and the third definition approach, which combined some elements of both the involvement and the intention-based approaches. In the article for prescribing a family firm, we will emphasize the first approach where family participation will be a priority. Therefore, in our sample, if the company has only one owner, we define it as a family firm. We treat farmers, private firms and family enterprises as family firms because according to Law, such businesses have only one owner or owners that could be from one family.

The Control Variables. This model will use two types of variables: the company-specific variables and the dummy variables. In the meantime, the dummy variables are also divided into three categories: the sector dummy variables, the year dummy variables and the urban dummy variable.

1. The company-specific variables are:

$\checkmark \quad$ Size (SIZE) - the natural log of total assets.

$\checkmark \quad$ Age (AGE) - measured by the number of years since a firm has been established.

$\checkmark \quad$ Investment Ratio (IR) - computed by dividing long-term investments by total assets.

$\checkmark \quad$ Financial Leverage Ratio (FLR) - defined by dividing the sum of short-term and longterm debts by the equity.

2. The sector dummy variables (SECDUM) are: 
Yusupov Jasurbek, Sakata Kei

Family Business and Financial Performance: What are the Effects of Tax Cut Policy on Them in

Uzbekistan?

$\begin{array}{ll}\checkmark & \text { Industry } \\ \checkmark & \text { Agriculture } \\ \checkmark & \text { Transport and communication } \\ \checkmark & \text { Construction } \\ \checkmark & \text { Trade and public catering } \\ \checkmark & \text { Procurement and Distribution } \\ \checkmark & \text { Housing and utilities }\end{array}$

3. The year dummy (YEARDUM) $=1$ for each year of the sample period.

4. The urban dummy (URBDUM) $=1$ if the firm is located in a metropolitan area.

\subsection{Data and Sample Selection}

Uzbekistan is comprised of twelve provinces, one autonomous republic, and one independent city (See Table 1). Meanwhile, the provinces include one capital city and many districts. For this investigation, we use data taken from the tax department of Andijan province, because all legal entities are the same type in all provinces except Tashkent city. We obtained data from Andijan city, the Asaka district and the Shahrihan District Tax Departments. This data contains information on annual Balance Sheets and Financial Reports submitted by firms to the local tax departments where they have been registered. From Balance Sheet long-term investments, total assets, total shareholder's equity, short-term debt, long-term debt and from a Financial Statement total sales, cost, pretax income, and net income were collected manually. Also, annually calculated taxes, the number of workers, registered date and other company-specific information such as the form type, and kind of activity were compiled.

Table 1: Administrative division of Uzbekistan.

\begin{tabular}{|l|l|l|}
\hline & & \\
& & Capital City \\
\hline 1 & Andijan Region & \\
\hline 2 & Bukhara Region & Andijan \\
\hline 3 & Fergana Region & Bukhara \\
\hline 4 & Jizzakh Region & Fergana \\
\hline 5 & Karakalpakstan Republic & Jizzakh \\
\hline 6 & Kashkadarya Region & Nukus \\
\hline 7 & Khorezm Region & Karshi \\
\hline 8 & Namangan Region & Urgench \\
\hline 9 & Navoiy Region & Namangan \\
\hline 10 & Samarkand Region & Navoiy \\
\hline 11 & Surkhandarya Region & Samarkand \\
\hline 12 & Syrdarya Region & Termez \\
\hline 13 & Tashkent City & Gulistan \\
\hline 14 & Tashkent Region & Tashkent \\
\hline
\end{tabular}

Source: https://en.wikipedia.org/wiki/Uzbekistan\#Administrative divisions 


\section{Yusupov Jasurbek, Sakata Kei}

Family Business and Financial Performance: What are the Effects of Tax Cut Policy on Them in Uzbekistan?

As of 31 December 2012, the total of all operating legal entities in Andijan province is 14673 (See Table 2). During the sample selection, banks were excluded because the Central Bank of Uzbekistan regulates them according to the Law about the Central Bank adopted on 21 December 1995. Moreover, associations, budget organizations, household farmers, public organizations, and trade union committees are omitted from the sample due to having no financial profit, and they have submitted reports to the local tax offices only related to salary. Furthermore, some government organizations, joint ventures and joint-stock companies also were removed from the sample considering that they have state share, and the government influenced their performance. Finally, firms which submitted incorrect reports or with a lot of missing data were also kept out from the sample. In the end, Andijan city had 2,787 legal entities of 1998 firms (72\%), the Asaka district had 1,035 legal entities of 555 firms (54\%), and the Shahrihan district had 931 legal entities of 595 firms that were kept for further analysis. Overall, we created unbalanced panel data from 2012 through 2015 on 3,148 non-banking/nongovernment firms that yielded 12,163 firm-years or observations.

Table 3 shows the number and percentage of family and non-family firms by sector. From there, we can see that family firms form $44 \%$ of our sample. By industry, the largest share comes from the agricultural sector, where family firms consist of almost $90 \%$. It is because Uzbekistan is one of the leading cultivators of cotton in the world, and its farmers mainly cultivate this product. The portion of family firms in other sectors is as follows: for industry $29 \%$, for transportation and communication $17 \%$, for construction $37 \%$, for trade and public catering $41 \%$, for procurement and distribution 31\%, and for housing and utilities $36 \%$. Therefore, in our empirical analysis, we will control for sector affiliation using dummy variables for each of them.

Table 2: The sample selection from Andijan province as of 01.01.2012.

\begin{tabular}{|c|c|c|c|c|c|c|c|c|c|c|c|c|c|}
\hline & & Types of regist & ered legal & ntities & & & & & & & & & \\
\hline & $\begin{array}{l}\text { The name of } \\
\text { cities/district } \\
\text { Tax } \\
\text { Departments }\end{array}$ & $\begin{array}{l}\text { Associations, } \\
\text { Banks, } \\
\text { Budget } \\
\text { organizations, } \\
\text { Government } \\
\text { organizations, } \\
\text { Household } \\
\text { farmers, } \\
\text { Public } \\
\text { organizations, } \\
\text { Trade Union } \\
\text { Committees }\end{array}$ & Farmers & Firms & $\begin{array}{l}\text { Joint- } \\
\text { ventures }\end{array}$ & \begin{tabular}{|l|} 
Joint- \\
stock \\
companies
\end{tabular} & LLCs & $\begin{array}{l}\text { Private } \\
\text { enterprises }\end{array}$ & $\begin{array}{l}\text { Rent } \\
\text { companies }\end{array}$ & $\begin{array}{l}\text { Small } \\
\text { enterprises }\end{array}$ & $\begin{array}{l}\text { Total by } \\
\text { district/city }\end{array}$ & $\begin{array}{l}\text { Selected } \\
\text { for } \\
\text { sample }\end{array}$ & $\begin{array}{l}\text { Share in } \\
\text { all } \\
\text { population }\end{array}$ \\
\hline 1 & $\begin{array}{l}\text { Andijan city Tax } \\
\text { Department }\end{array}$ & 423 & 2 & 224 & 20 & 27 & 1575 & 499 & 1 & 16 & 2787 & 1998 & 72 \\
\hline 2 & $\begin{array}{l}\text { Asaka district } \\
\text { Tax } \\
\text { Department }\end{array}$ & 208 & 285 & 49 & 2 & 9 & 229 & 241 & & 12 & 1035 & 555 & 54 \\
\hline 3 & $\begin{array}{l}\text { Shahrihan } \\
\text { district Tax } \\
\text { Department }\end{array}$ & 197 & 314 & 44 & 9 & 4 & 216 & 145 & & 2 & 931 & 595 & 64 \\
\hline 17 & $\begin{array}{l}\text { Other } 13 \\
\text { district Tax } \\
\text { Departments }\end{array}$ & 1806 & 4987 & 446 & 23 & 43 & 1096 & 1400 & 5 & 114 & 9920 & 0 & 0 \\
\hline & $\begin{array}{l}\text { Total by } \\
\text { Region }\end{array}$ & 2634 & 5588 & 763 & 54 & 83 & 3116 & 2285 & 6 & 144 & 14673 & 3148 & 21 \\
\hline
\end{tabular}

Source: Andijan region Tax Department database. Authors' calculation.

Table: Number and percent of family and non-family firms by Sector $(N=12163)$

$\begin{array}{lll}\text { Sector's first Sector name } & \begin{array}{l}\text { Nonfamily } \\ \text { Code }\end{array} & \text { Firms }\end{array}$ Family Firms $\begin{aligned} & \text { Percent Family } \\ & \text { in Sector }\end{aligned}$




\section{Yusupov Jasurbek, Sakata Kei}

Family Business and Financial Performance: What are the Effects of Tax Cut Policy on Them in Uzbekistan?

\begin{tabular}{|c|c|c|c|c|}
\hline 2 & Agriculture & 57 & 466 & 89.1 \\
\hline 5 & Transport and communicat & 79 & 17 & 17.7 \\
\hline 6 & Construction & 206 & 124 & 37.6 \\
\hline 7 & Trade and public catering & 589 & 417 & 41.5 \\
\hline 8 & Procurement and Distributi & 135 & 61 & 31.1 \\
\hline 9 & Housing and utilities & 164 & 95 & 36.7 \\
\hline TOTAL: & & 1749 & 1399 & 44.4 \\
\hline
\end{tabular}

Source: Andijan city Tax Department (2012), Asaka district Tax Department (2012) and Shahrihan district Tax Department (2012). Author's calculation.

\subsection{Descriptive Analysis of the Differences Between Family and Non-Family Businesses}

Table 4 presents three panels of descriptive information for our sample of companies. Panel A provides means, standard deviations, and maximum and minimum values of the key variables in our full sample. Panel B shows the results of the difference of means tests between family and non-family firms. Panel $\mathrm{C}$ provides a simple correlation matrix for the variables in the sample.

Table 4: Descriptive data for family and non-family firms ( $n=3148$ firms).

\begin{tabular}{|c|c|c|c|c|c|}
\hline \multicolumn{6}{|c|}{ Panel A: Summary Statistics for the Full Sample } \\
\hline & Observations & Mean & Std. Dev. & Min & Max \\
\hline Number of employee & 12,163 & 12 & 52 & 1 & 2488 \\
\hline Return on Assets (ROA) (\%) & 12,163 & 14.70 & 18.96 & 0 & 100 \\
\hline Net Profit Margin (NPM) (\%) & 12,082 & 11.41 & 13.78 & 0 & 100 \\
\hline Return on Equity (ROE) (\%) & 10,662 & 25.84 & 31.49 & 0 & 200 \\
\hline Financial Leverage Ratio (FLR) (\%) & 10,495 & 148.22 & 231.97 & 0 & 1,498 \\
\hline Investment Ratio (\%) & 12,163 & 0.84 & 5.95 & 0 & 100 \\
\hline SIZE & 12,163 & 11.27 & 1.92 & 1 & 21 \\
\hline AGE & 12,163 & 6.83 & 4.75 & 0 & 43 \\
\hline LN (Sales) & 12,163 & 11.21 & 2.14 & 0 & 19 \\
\hline LN (Net Income) & 11,700 & 8.40 & 2.28 & 0 & 17 \\
\hline LN (Number of employee) & 12,163 & 1.61 & 1.12 & 0 & 8 \\
\hline LN (Wage) & 12,061 & 9.06 & 1.60 & -4 & 15 \\
\hline LN (Cost) & 12,014 & 10.80 & 2.28 & 0 & 19 \\
\hline
\end{tabular}

Panel B: Difference of Means Tests 
Yusupov Jasurbek, Sakata Kei

Family Business and Financial Performance: What are the Effects of Tax Cut Policy on Them in Uzbekistan?

\begin{tabular}{|c|c|c|c|}
\hline & $\begin{array}{l}\text { Family } \\
\text { Firms }\end{array}$ & $\begin{array}{l}\text { Nonfamily } \\
\text { Firms }\end{array}$ & \\
\hline Number of firms & 1399 & 1749 & \\
\hline Number of employee & 8 & 15 & $-6.94 * * *$ \\
\hline Return on Assets (ROA) (\%) & 15.47 & 14.09 & $3.98 * * *$ \\
\hline Net Profit Margin (NPM) (\%) & 11.09 & 11.66 & $-2.25 * *$ \\
\hline Return on Equity (ROE) (\%) & 28.17 & 24.06 & $6.68 * * *$ \\
\hline Financial Leverage Ratio (FLR) (\%) & 168.88 & 132.63 & $7.94 * * *$ \\
\hline Investment Ratio (\%) & 0.50 & 1.11 & $-5.62 * * *$ \\
\hline SIZE & 10.84 & 11.62 & $-22.78 * * *$ \\
\hline AGE & 7.94 & 5.94 & $23.56 * * *$ \\
\hline LN (Sales) & 10.92 & 11.44 & $-13.45^{* * *}$ \\
\hline LN (Net Income) & 8.13 & 8.61 & $-11.30 * * *$ \\
\hline LN (Wage) & 8.85 & 9.23 & $-13.01 * * *$ \\
\hline LN (Cost) & 10.55 & 11.00 & $-10.68 * * *$ \\
\hline
\end{tabular}

Panel C: Correlation Data (continued)

\begin{tabular}{|c|c|c|c|c|c|c|c|c|c|c|c|c|c|}
\hline & & (1) & (2) & (3) & (4) & $(5)$ & (6) & (7) & $(8)$ & (9) & (10) & (11) & $(12)$ \\
\hline (1) & $\mathrm{FB}$ & 1 & & & & & & & & & & & \\
\hline (2) & Return on Assets (ROA) (\%) & 0.04 & 1 & & & & & & & & & & \\
\hline (3) & Net Profit Margin (NPM) (\%) & -0.02 & 0.42 & 1 & & & & & & & & & \\
\hline (4) & Return on Equity (ROE) (\%) & 0.07 & 0.79 & 0.32 & 1 & & & & & & & & \\
\hline (5) & Financial Leverage Ratio (FLR) (\%) & 0.07 & -0.20 & -0.15 & 0.17 & 1 & & & & & & & \\
\hline (6) & Investment Ratio (\%) & -0.05 & -0.03 & 0.09 & -0.05 & -0.03 & 1 & & & & & & \\
\hline (7) & SIZE & -0.20 & -0.17 & 0.01 & -0.19 & 0.03 & 0.13 & 1 & & & & & \\
\hline (8) & AGE & 0.21 & -0.05 & -0.06 & -0.07 & -0.02 & 0.01 & 0.08 & 1 & & & & \\
\hline (9) & LN (Sales) & -0.11 & 0.16 & -0.19 & 0.12 & -0.02 & 0.04 & 0.70 & 0.10 & 1 & & & \\
\hline (10) & LN (Net Income) & -0.09 & 0.44 & 0.32 & 0.37 & -0.12 & 0.07 & 0.63 & 0.04 & 0.76 & 1 & & \\
\hline (11) & LN (Wage) & -0.11 & 0.01 & -0.13 & 0.02 & 0.05 & 0.04 & 0.56 & 0.11 & 0.61 & 0.47 & 1 & \\
\hline (12) & LN (Cost) & -0.08 & 0.06 & -0.14 & 0.04 & 0.01 & 0.06 & 0.62 & 0.17 & 0.73 & 0.57 & 0.76 & 1 \\
\hline
\end{tabular}

In Panel $A$, the average number of workers in the firm is 12 . However, there are a lot of companies with only one employee, and this person owns the enterprise. The univariate analysis using time-series average underlines that in terms of performance, the average firm in the sample has a mean return on assets (ROA) of $14.7 \%$. The performance indicator in terms of net profit margin (NPM) consists of $11.41 \%$. Among them, the mean return on equity (ROE) is appreciable, and it is $25.84 \%$. From company-specific variables, the highest mean comes from the financial leverage ratio (FLR), which is equal to $148.22 \%$. It means that in the sample companies, they have about 1.5 times more obligations than their equity.

Moreover, the average investment ratio (IR) is relatively small, $0.84 \%$, which leads us to conclude that many firms are not so eager to make long-term investments. In the full sample, the average age of enterprises is about seven years. If we consider the sample that consists of companies which were established since the independence year 1991 until 2012, seven years of means shows that not so many firms survived. Most new businesses are included in the sample.

Panel B presents the difference of means test for variables between family firms and non-family firms. The sample consists of 1,399 family firms, and it represents about $44 \%$ of all the samples. In the family firms, there is an average of eight employees, and in the non-family firms, they employ on average, fifteen workers. As mentioned in previous chapters, family firms are only small and medium-sized. Therefore, employees differ considerably from the large non-family companies. In terms of performance, the sample shows that family firms perform slightly better than non-family firms with the average return on assets value of $15.47 \%$, whereas, for non- 
family firms, it is equal to $14.09 \%$. The positive difference between these two types of companies in the term of return on assets that vary from zero and are statistically significant in $1 \%(t=3.98)$. However, in the terms of net profit margin (NPM), non-family companies perform better than family companies, and average values are 11.66 and 11.09 , respectively. The negative difference also varies from zero, and it is statistically significant in $5 \%(t=-2.25)$. The mean of return on equity (ROE) for family firms noticeably differs from their counterparts. For family firms, their equity is on average $28.17 \%$ of profits, and in non-family firms, it is $24.06 \%$ which has a significant positive difference of $(t=6.68)$. The mean of financial leverage ratio (FLR) shows that family companies have about $36 \%$ more obligations than their equity $(t=7.94)$. The investment ratio (IR) is minimal for family companies at $0.5 \%$, and non-family firms have $1.11 \%$ value on average. The negative difference also varies from zero, and, it is statistically significant at $1 \% \quad(t=-5.62)$. In the term of total assets, revenue, net income, wage and cost of family firms that have a lower mean than non-family firms, these negative differences are all statistically significant. It can be explained by the size of family firms. As mentioned before, family firms mainly used to be small companies. However, on average the age of family firms is eight years, whereas non-family firms show a lower age-of six years. The reason why family businesses survive longer can be justified with the privatization process during the early independence years in Uzbekistan. During that period, the government emphasized creating new firms based on private property. Therefore, private companies are created first, and some of these companies are still operating now.

In the simple correlation matrix shown in Panel $\mathrm{C}$, a family business has a positive correlation with return on assets (ROA), return on equity (ROE), financial leverage ratio (FLR), firm age, and a negative correlation with a net profit margin (NPM), investment ratio (IR), firm size, the log of revenue, the log of net income, log of wage and log of cost. Moreover, return on assets (ROA) positively correlated with a net profit margin (NPM), return on equity (ROE), a log of revenue and log of net income. It has a negative correlation with the financial leverage ratio (FLR) and a log of total assets. Even though it has both positive and negative correlation with other variables such as investment ratio (IR), firm age, a log of wage and a log of cost, the correlation coefficient is too small and near to zero.

\subsection{The Analysis of Family Ownership and Firm Performance}

To explain the relationship between a family business and firm performance, we run the regression on the model (1) and get the results shown in Table 5.

Table 5: Financial performance regression results.

\begin{tabular}{|c|c|c|c|}
\hline \multirow{2}{*}{ Independent variables } & \multicolumn{3}{|c|}{ Dependent variables } \\
\hline & ROA & NPM & ROE \\
\hline & 1 & 2 & 3 \\
\hline \multirow[t]{2}{*}{ FB } & $2.0286 * * *$ & $0.8307^{*}$ & $3.1172 * * *$ \\
\hline & $(3.230)$ & $(1.720)$ & $(2.805)$ \\
\hline \multirow[t]{2}{*}{ Investment Ratio } & -0.0169 & $0.1004 * *$ & -0.0850 \\
\hline & $(-0.468)$ & $(2.032)$ & $(-1.552)$ \\
\hline \multirow[t]{2}{*}{ FLR } & $-0.0113 * * *$ & $-0.0063 * * *$ & $0.0224 * * *$ \\
\hline & $(-12.762)$ & $(-9.856)$ & $(8.936)$ \\
\hline \multirow[t]{2}{*}{ SIZE } & $-2.1763 * * *$ & $0.3962 * * *$ & $-3.5583 * * *$ \\
\hline & $(-12.645)$ & $(3.480)$ & $(-12.100)$ \\
\hline AGE & $-0.1381 * *$ & $-0.1995 * * *$ & $-0.3132 * * *$ \\
\hline
\end{tabular}




\section{Yusupov Jasurbek, Sakata Kei}

Family Business and Financial Performance: What are the Effects of Tax Cut Policy on Them in Uzbekistan?

\begin{tabular}{llll} 
& $(-2.409)$ & $(-4.349)$ & $(-2.949)$ \\
Agriculture & $-3.5109 * * *$ & $1.5049 * *$ & $-4.2256^{* *}$ \\
TransportandCommunication & $(-3.799)$ & $(1.963)$ & $(-2.446)$ \\
Construction & 0.8217 & 0.5496 & -1.5534 \\
& $(0.444)$ & $(0.387)$ & $(-0.525)$ \\
TradeandPubliccatering & $5.5477 * * *$ & $-1.2584 *$ & $8.2319 * * *$ \\
& $(5.530)$ & $(-1.760)$ & $(5.090)$ \\
ProcurementandDistribution & $-1.6514 * *$ & $-3.1243 * * *$ & $-2.2619 *$ \\
HousingandUtilities & $(-2.321)$ & $(-5.589)$ & $(-1.813)$ \\
URBDUM & -1.2040 & $4.5666 * * *$ & -2.5429 \\
Intercept & $(-0.911)$ & $(4.012)$ & $(-1.144)$ \\
Year effect & $-2.0938 * *$ & $3.3256 * * *$ & -2.8110 \\
Observations & $(-1.968)$ & $(3.353)$ & $(-1.465)$ \\
Number of firms & $1.3950 * *$ & $2.3851 * * *$ & $3.0822 * * *$ \\
\hline
\end{tabular}

Robust z-statistics in parentheses

$* * * \mathrm{p}<0.01, * * \mathrm{p}<0.05, * \mathrm{p}<0.1$

Column 1 presents the results using a return on assets (ROA) as an outcome variable. It shows that family firms have a $2.03 \%$ higher ROA coefficient compared to their peers $(\beta=2.03$, $p<0.01)$. In the model, the coefficients of the other variables are also remarkable. The model shows that FLR $(\beta=-0.01, p<0.01)$, SIZE $(\beta=-2.17, p<0.01)$ and AGE $(\beta=-0.13, p<0.05)$ have an adverse impact on ROA. Moreover, when we take into account the part of companies in our sample pertaining to the reference "Industry" sector as a reference group, firms in the "Agriculture" sector $(\beta=-3.51, p<0.01)$, the "Trade and Public catering" sector $(\beta=-1.65$, $p<0.05)$ and the "Housing and Utilities" sector $(\beta=-2.09, p<0.05)$ are falling behind. Only firms in the "Construction" sector $(\beta=5.54, p<0.01)$ are outperforming. In other sectors such as "Transport and Communication" and "Procurement and Distribution" there are no statistically significant differences between the "Industry" sector in terms of ROA. Furthermore, firms that are located in the city show $1.39 \%$ higher performances compared to their counterparts.

In Column 2 the results are shown using net profit margin (NPM) as an outcome variable. In this case, family firms are also showing $0.83 \%$ higher performance than non-family firms $(\beta=0.83, p<0.1)$. For this outcome variable, the relationship between other independent variables differs quite a lot compared to ROA. The results show that there is a positive impact of investment ratio on NPM $(\beta=0.1, p<0.05)$. The FLR $(\beta=0.001, p<0.01)$ and AGE $(\beta=0.19$, $p<0.01$ ) have a negative relationship with NPM. However, companies with higher assets are used to have better performances compared to small businesses $(\beta=0.39, p<0.01)$. In terms of 
sector differences, agricultural firms $(\beta=1.5, p<0.05)$ and companies that are in the sector of "Procurement and Distribution" $(\beta=4.56, p<0.01)$ have higher performance coefficients than industrial businesses. The "Trade and Public Catering" $(\beta=-3.12, p<0.01)$ and "Construction" sector $(\beta=-1.25, p<0.1)$ firms have been underperforming compared to the enterprises of the "Industry" sector. There is no significant difference between the "Industry" and the "Transport and Communication" sectors in terms of NPM.

Column 3 highlights the impact of family businesses on other metrics of financial performance - return on equity. The relationship between ROE and family business shows that family firms outperform their counterparts in terms of ROE by $3.11 \%$. The coefficients of other variables are also interesting. They show that ROE is significantly negatively related to SIZE $(\beta=-3.55$, $p<0.01)$, AGE $(\beta=-0.31, p<0.01)$ and at the same time positively related to FLR $(\beta=0.02$, $p<0.01)$. Compared to the Industry sector firms, the Agriculture sector firms have $4.2 \%$, the Trade and Public Catering sector firms have a 2.2\% lower ROE ratio. However, the Construction sector firms have $8.23 \%$ more ROE than the Industry sector firms. Moreover, companies located in urban areas have $3.08 \%$ higher ROE compared to businesses situated in district areas.

Taken as a whole, the results suggest that family businesses show superior financial performance when controlling for a set of company-specific, sector affiliation and location variables. Furthermore, the Investment ratio has a positive impact on NPM, FLR has a negative impact on ROA and NPM, but it has a positive effect on ROE. From the results also we can observe that company's age and size has a negative effect on financial performance. When we control for sector affiliation, the regression results of ROA and ROE are almost the same in the sign and significance. Compared to the Industry sector, Agricultural, Trade and Public Catering, Housing and Utility firms are underperforming, while only the Construction firms are outperforming. In terms of NPM, the results are contradictory to the other performance indicators. In this case, SIZE is positively related to NPM; on the other hand, the Agricultural and Procurement and Distribution firms also are outperforming the Industrial firms. In all the regression results, companies located in urban areas are showing better performance than businesses located in district areas.

\subsection{The Effects of Tax Cut Policy on Family Businesses}

As mentioned in previous chapters, family firms in Uzbekistan are organized exclusively as small and micro-enterprises. Therefore, all privileges that are given to SMEs by the government will also be applied to the family firms. According to the Decree of the President of the Republic of Uzbekistan "About the forecast of main macroeconomic indicators and parameters of the State budget of the Republic of Uzbekistan for 2015" adopted in 2014, from 2015 SMEs are given tax privileges in the form of decreasing unique social payments from $25 \%$ to $15 \%$ - In this section, we will investigate the effect of this tax privilege on financial performance and other indicators of the small and micro enterprises by using the difference in the difference estimator. In our sample, we will identify SMEs as a focus group and large companies as a control group. The period until 2015 will be the BEFORE period, and 2015 will be the AFTER period. From here, we will get our difference-in-difference estimator as an interaction between SMEs AFTER period 2015. To analyze the policy effect, we employ two models which differ from each other in outcome variables:

$y_{i t}=\tau_{1} S M E_{i t}+\tau_{2}$ year2015 $+\tau_{3}\left(S M E_{i t} *\right.$ year2015) $+Z \delta+v_{i t}$

where $v_{i t}=\mu_{i}+\omega_{i t}$

$y_{i t}$ denotes the performance of the firm such as ROA, NPM, ROE and firm-specific indicators such as Sales, Cost, Net Income and Wages in the log form.

$Z$ is a vector of other control variables. $Z$ includes the Investment Ratio, FLR, SIZE, AGE, SECDUM, YEARDUM, URBDUM. 
$v_{i t}$ contains $\mu_{i}$, which is an individual random effect, and $\omega_{i t}$ follows iid.

We use all observations first, and then 2014 and 2015 samples to estimate equation (2).

The parameter of interest is $\tau_{3}$ which shows the expected mean change in the outcome variables between the different two groups after the tax rate change.

Table 6 represents the results of the (2) model using all observations where outcome variables are firms' financial performance indicators. As an effect of the policy, DID estimators are showing a positive relationship between performance indicators, however only the coefficient of the DID estimator of ROA is statistically significant with $10 \%$, while the others are insignificant. It means that SMEs have $2.82 \%$ higher ROA in 2015 compared to large companies $(\beta=2.82, p<0.1)$. However, the results may not be robust. Therefore, to check the robustness of DID estimations, we will conduct a "Placebo test". For conducting a "Placebo test," we use data for prior periods from 2012 to 2014 and redo the DID comparing 2012 with 2013 and 2013 with 2014. If this placebo DID is non-zero, there are good chances that our estimate comparing the year 2014 and year 2015 is biased as well.

Table 6: Difference in Difference Estimation Results for Financial Performance Indicators

\begin{tabular}{llll}
\hline \multirow{2}{*}{ Independent variables } & $\boldsymbol{R O A}$ & NPM & ROE \\
\cline { 2 - 4 } & $\mathbf{( 1 )}$ & $\mathbf{( 2 )}$ & $\mathbf{( 3 )}$ \\
\hline SME & & & \\
& & & \\
y15 & -2.3677 & 0.7876 & -2.0089 \\
& $(-1.355)$ & $(0.432)$ & $(-0.647)$ \\
y15xSME & $-3.1723 * *$ & -1.4626 & -3.0302 \\
& $(-2.110)$ & $(-1.164)$ & $(-1.177)$ \\
Intercept & $2.8220 *$ & 1.8297 & 1.2002 \\
Observations & $(1.840)$ & $(1.432)$ & $(0.457)$ \\
Number of firms & $44.7366 * * *$ & $7.5951 * * *$ & $67.4772 * * *$ \\
\hline
\end{tabular}

Robust z-statistics in parentheses

$* * * \mathrm{p}<0.01, * * \mathrm{p}<0.05, * \mathrm{p}<0.1$

Note: Controlled variables such as Investment Ratio, FLR, SIZE, AGE, SECDUM, and URBDUM ar reported.

Table 7 shows the estimated results of DID using the periods between 2012 and 2013. The results suggest that there is no significant difference between SMEs and large companies in 2013. Other placebo DID results for the periods between 2013 and 2014 are shown in Table 8. These results also show the insignificant difference between SMEs and large firms in 2014 compared to 2013. It seems our first DID result remains robust and unbiased after the Placebo test. However, it is better to check for another period year when the policy came into force and a previous year using 2015 and 2014 samples. Interestingly, we do not get any statistically significant DID results shown in Table 9 for this period. It may lead us to make a conclusion that our first result which SMEs have $2.82 \%$ higher ROA in 2015 compared to large companies 


\section{Yusupov Jasurbek, Sakata Kei}

Family Business and Financial Performance: What are the Effects of Tax Cut Policy on Them in Uzbekistan?

remains not so robust, and there is no difference between SMEs and large companies in terms of financial performance after the policy was implemented.

Table 7: Placebo DID estimation results for Financial performance Indicators for period 2012-2013

\section{Independent variables}

\begin{tabular}{lll}
$R O A$ & NPM & ROE \\
\hline$(1)$ & (2) & (3)
\end{tabular}

\begin{tabular}{llll} 
SME & -3.4917 & 0.5684 & -0.4245 \\
& $(-1.621)$ & $(0.269)$ & $(-0.133)$ \\
y13 & -0.7655 & -0.3000 & 1.5259 \\
& $(-0.516)$ & $(-0.330)$ & $(0.577)$ \\
y13xSME & 1.4229 & 0.1921 & -0.0047 \\
& $(0.935)$ & $(0.205)$ & $(-0.002)$ \\
Intercept & $47.9956 * * *$ & $7.9099 * * *$ & $68.1542^{* * *}$ \\
& $(13.259)$ & $(3.014)$ & $(12.234)$ \\
& & & \\
Observations & 5,269 & 5,224 & 5,199 \\
Number of firms & 2,777 & 2,770 & 2,750 \\
\hline
\end{tabular}

Robust z-statistics in parentheses

$* * * \mathrm{p}<0.01, * * \mathrm{p}<0.05, * \mathrm{p}<0.1$

Note: Controlled variables such as Investment Ratio, FLR, SIZE, AGE, SECDUM, and URBDUM ar reported.

Table 8: Placebo DID estimation results for Financial performance Indicators for period 2013-2014

\begin{tabular}{llll}
\hline \multirow{2}{*}{ Independent variables } & $\boldsymbol{R O A}$ & $\boldsymbol{N} \boldsymbol{N M}$ & $\boldsymbol{R O E}$ \\
\cline { 2 - 4 } & $\mathbf{( 1 )}$ & $\mathbf{( 2 )}$ & $\mathbf{( 3 )}$ \\
\hline \multirow{2}{*}{ SME } & & & \\
& -1.3635 & 1.1217 & -1.1984 \\
y14 & $(-0.769)$ & $(0.606)$ & $(-0.348)$ \\
& -1.1320 & 0.3282 & -0.9336 \\
y14xSME & $(-0.904)$ & $(0.383)$ & $(-0.311)$ \\
& 1.1327 & -0.3456 & -0.0317 \\
Intercept & $(0.876)$ & $(-0.386)$ & $(-0.010)$ \\
& $40.1618^{* * *}$ & $6.2756 * *$ & $64.3530 * * *$ \\
& $(13.047)$ & $(2.434)$ & $(11.368)$
\end{tabular}




\section{Yusupov Jasurbek, Sakata Kei}

Family Business and Financial Performance: What are the Effects of Tax Cut Policy on Them in Uzbekistan?

\begin{tabular}{llll} 
Observations & 5,259 & 5,234 & 5,195 \\
Number of firms & 2,769 & 2,765 & 2,745 \\
\hline
\end{tabular}

Robust z-statistics in parentheses

$* * * \mathrm{p}<0.01, * * \mathrm{p}<0.05, * \mathrm{p}<0.1$

Note: Controlled variables such as Investment Ratio, FLR, SIZE, AGE, SECDUM, and URBDUM ar reported.

Table 9: Difference in Difference estimation results for Financial performance Indicators for period 2014-2015

\begin{tabular}{llll}
\hline \multirow{2}{*}{ Independent variables } & $\boldsymbol{R O A}$ & $\boldsymbol{N P M}$ & $\boldsymbol{R O E}$ \\
\cline { 2 - 4 } & $\mathbf{( 1 )}$ & $\mathbf{( 2 )}$ & $\mathbf{( 3 )}$ \\
\hline \multirow{2}{*}{ SME } & & & \\
& -0.3917 & 0.8192 & -1.4662 \\
y15 & $(-0.206)$ & $(0.420)$ & $(-0.395)$ \\
& -2.2145 & -1.1855 & -2.1612 \\
y15xSME & $(-1.427)$ & $(-0.936)$ & $(-0.823)$ \\
& 1.6467 & 1.5622 & 0.4746 \\
Intercept & $(1.040)$ & $(1.212)$ & $(0.177)$ \\
& $36.9878^{* * *}$ & $8.4215^{* * *}$ & $58.7582^{* * *}$ \\
& $(10.799)$ & $(3.303)$ & $(9.666)$ \\
Observations & & & \\
Number of firms & 5,226 & 5,202 & 5,169 \\
\hline
\end{tabular}

Robust z-statistics in parentheses

$* * * \mathrm{p}<0.01, * * \mathrm{p}<0.05, * \mathrm{p}<0.1$

Note: Controlled variables such as Investment Ratio, FLR, SIZE, AGE, SECDUM, and URBDUM ar reported.

In the next stage, we will examine the effects of policy on firm-specific indicators like Sales, Net Income, Cost and Wages. Table 10 presents the results of the DID estimation for firm-specific indicators. The coefficients of the DID estimators reveal that there is no difference between the SMEs and large companies in 2015 in terms of Sales, Net Income and Cost except Wages. The SMEs, only in Wages, were using $18.2 \%$ more wages for their employees in 2015 ( $\beta=0.18$, $p<0.1$ ). To be confident in the coefficient, it is better to check it for robustness as we did in the performance indicators by conducting a Placebo test dividing the period into two parts: 2012 with 2013 and 2013 with 2014. Table 11 and Table 12 show the results of the Placebo DID estimation of these two different periods. The results of Table 11 reveal that there is no difference between SMEs and large companies in 2013 compared to 2012.

Similarly, as is shown in Table 12 , we do not find statistically significant differences in 2014 compared to 2013 between our Treatment and Control groups. The final stage is to estimate equation (2) using only 2014-and 2015 samples, and the results are shown in Table 


\section{Yusupov Jasurbek, Sakata Kei}

Family Business and Financial Performance: What are the Effects of Tax Cut Policy on Them in Uzbekistan?

13. The results highlight that there is only a difference in terms of Wage, and it is statistically significant with $10 \%(\beta=0.18, p<0.1)$ which leads us to conclude that our first DID result is robust.

\begin{tabular}{|c|c|c|c|c|}
\hline & LN (Sales) & LN (Net Income & LN (Wage) & $L N($ Cost $)$ \\
\hline & $(1)$ & (2) & (3) & (4) \\
\hline SME & $\begin{array}{l}-0.4397 * * * \\
(-2.817)\end{array}$ & $\begin{array}{l}-0.0095 \\
(-0.044)\end{array}$ & $\begin{array}{l}-0.9478 * * * \\
(-6.130)\end{array}$ & $\begin{array}{l}-0.5444 * * * \\
(-3.091)\end{array}$ \\
\hline y15 & $\begin{array}{l}-0.0908 \\
(-0.819)\end{array}$ & $\begin{array}{l}-0.2988 \\
(-1.621)\end{array}$ & $\begin{array}{l}-0.1635^{*} \\
(-1.677)\end{array}$ & $\begin{array}{l}-0.1353 \\
(-1.169)\end{array}$ \\
\hline y15xSME & $\begin{array}{l}0.0295 \\
(0.262)\end{array}$ & $\begin{array}{l}0.2885 \\
(1.549)\end{array}$ & $\begin{array}{l}0.1822 * \\
(1.838)\end{array}$ & $\begin{array}{l}0.0621 \\
(0.527)\end{array}$ \\
\hline Intercept & $\begin{array}{l}4.3153^{* * *} \\
(14.225)\end{array}$ & $\begin{array}{l}0.8738^{* *} \\
(2.485)\end{array}$ & $\begin{array}{l}4.4212 * * * \\
(17.870)\end{array}$ & $\begin{array}{l}4.1263 * * * \\
(12.499)\end{array}$ \\
\hline Observations & 10,495 & 10,178 & 10,415 & 10,371 \\
\hline Number of firms & 2,916 & 2,879 & 2,912 & 2,891 \\
\hline
\end{tabular}

Table 10: Placebo DID estimation results for Firm-specific Indicators for period 2012-2013

\section{Independent variables}

\section{LN (Sales) LN (Net Income) LN (Wage) LN (Cost)}

(1) (2) (3) (4)

\begin{tabular}{lllll} 
SME & $-0.6722 * * *$ & -0.1209 & $-0.9753 * * *$ & $-0.7749 * * *$ \\
& $(-3.789)$ & $(-0.480)$ & $(-5.674)$ & $(-3.972)$ \\
y13 & 0.0553 & 0.1178 & $0.2668 * * *$ & 0.0353 \\
& $(0.522)$ & $(0.727)$ & $(3.280)$ & $(0.311)$ \\
y13xSME & 0.0848 & 0.0189 & -0.1077 & 0.0994 \\
& $(0.788)$ & $(0.115)$ & $(-1.291)$ & $(0.863)$ \\
Intercept & $5.0012^{* * *}$ & $1.3318 * * *$ & $4.4812 * * *$ & $4.7287 * * *$ \\
& $(14.071)$ & $(3.308)$ & $(16.869)$ & $(12.304)$ \\
& & & & \\
Observations & 5,269 & 5,116 & 5,197 & 5,224 \\
Number of firms & 2,777 & 2,716 & 2,763 & 2,753 \\
\hline
\end{tabular}

Robust z-statistics in parentheses

$* * * \mathrm{p}<0.01, * * \mathrm{p}<0.05, * \mathrm{p}<0.1$ 
Yusupov Jasurbek, Sakata Kei

Family Business and Financial Performance: What are the Effects of Tax Cut Policy on Them in Uzbekistan?

Note: Controlled variables such as Investment Ratio, FLR, SIZE, AGE, SECDUM, and URBDUM are not repc Table 11: Placebo DID estimation results for Firm-specific Indicators for period 2013-2014

\section{Independent variables}

\section{LN (Sales) LN (Net Income) LN (Wage) LN (Cost)}

(1) (2) (3) (4)

\begin{tabular}{lllll} 
SME & $-0.4231^{* *}$ & -0.0475 & $-1.0919 * * *$ & $-0.5047 * * *$ \\
& $(-2.424)$ & $(-0.195)$ & $(-6.691)$ & $(-2.577)$ \\
y14 & -0.0736 & -0.1293 & $0.1565 *$ & -0.0624 \\
& $(-0.541)$ & $(-0.724)$ & $(1.939)$ & $(-0.463)$ \\
y14xSME & 0.1134 & 0.1537 & 0.0519 & 0.1207 \\
& $(0.827)$ & $(0.850)$ & $(0.625)$ & $(0.884)$ \\
Intercept & $4.2557 * * *$ & 0.5919 & $4.9037 * * *$ & $4.0403^{* * *}$ \\
& $(12.802)$ & $(1.502)$ & $(18.413)$ & $(10.961)$ \\
& & & & \\
Observations & 5,259 & 5,110 & 5,241 & 5,199 \\
Number of firms & 2,769 & 2,710 & 2,768 & 2,741 \\
\hline
\end{tabular}

Robust z-statistics in parentheses

$* * * \mathrm{p}<0.01, * * \mathrm{p}<0.05, * \mathrm{p}<0.1$

Note: Controlled variables such as Investment Ratio, FLR, SIZE, AGE, SECDUM, and URBDUM are not repc

Table 12: Difference in Difference estimation results for Firm-specific Indicators for period 2014-2015

\begin{tabular}{|c|c|c|c|c|}
\hline \multirow{2}{*}{ Independent variables } & LN (Sales) & LN (Net Income) & LN (Wage) & $L N($ Cost) \\
\hline & (1) & (2) & (3) & $(4)$ \\
\hline \multirow[t]{2}{*}{ SME } & -0.1680 & 0.2075 & $-0.9138 * * *$ & -0.2534 \\
\hline & $(-0.980)$ & $(0.854)$ & $(-5.614)$ & $(-1.336)$ \\
\hline \multirow[t]{2}{*}{ y15 } & -0.0187 & -0.2138 & $-0.2993 * * *$ & -0.0566 \\
\hline & $(-0.153)$ & $(-1.159)$ & $(-3.147)$ & $(-0.441)$ \\
\hline \multirow[t]{2}{*}{ y15xSME } & -0.0890 & 0.1518 & $0.1791^{*}$ & -0.0727 \\
\hline & $(-0.712)$ & $(0.813)$ & $(1.841)$ & $(-0.556)$ \\
\hline \multirow[t]{2}{*}{ Intercept } & $2.7738^{* * *}$ & -0.4307 & $4.1073 * * *$ & $2.5413 * * *$ \\
\hline & $(8.598)$ & $(-1.129)$ & $(15.721)$ & (7.109) \\
\hline Observations & 5,226 & 5,062 & 5,218 & 5,147 \\
\hline
\end{tabular}


Yusupov Jasurbek, Sakata Kei

Family Business and Financial Performance: What are the Effects of Tax Cut Policy on Them in

Uzbekistan?

Number of firms

2,759

2,706

2,759

2,724

Robust z-statistics in parentheses

$* * * \mathrm{p}<0.01, * * \mathrm{p}<0.05, * \mathrm{p}<0.1$

Note: Controlled variables such as Investment Ratio, FLR, SIZE, AGE, SECDUM, and URBDUM arє reported.

Taken as a whole, the results reveal that there is no impact of tax cut policy on the financial performance of SMEs in the short-run. Moreover, we could not find any change in sales, net income and cost of the firms after the policy implementation. On the other hand, there is about $18 \%$ increase in wages of SMEs compared to large companies after the tax change. Gathering these pieces leads to the following interpretation. The base for taxation of the USP is the payroll fund of a firm. In other words, the higher the payroll fund of a firm is, the higher the tax payment is. This, in turn, increases the cost of production. Therefore, the high payroll tax rates gave firms incentives to conceal the real payroll fund and to pay their workers' salary in cash partially. This practice is called the "envelope method". After the tax cut policy had been implemented in 2015, a sharp decrease in the tax rate had removed incentives for SMEs to conceal "real" payrolls and increased their wages. No effects of the tax change on the cost of production and the net income means that the increases in wages off set the tax savings.

\section{Conclusion and Further Studies}

This research examines whether there are any differences between family firms and non-family businesses in terms of financial performance. It evaluates the effects of a tax cut in 2015 on SMEs. To answer these questions, we used large panel data from 3,148 firms for the period 2012-2015 with a total of 12,163 observations and obtained these conclusions:

* Family businesses have on average $2.02 \%$ higher ROA than non-family firms;

* In terms of ROE, they show 3.11\% higher performance compared to their counterparts;

* There is a small difference in NPM, with family firms having an $0.83 \%$ higher indicator compared to non-family firms;

* Family firms used to be older than other companies;

* Family firms are more financially constrained than other businesses types;

* Firms located in urban areas demonstrate higher performance than firms located in district areas;

* At least in the short-run, there is no evidence of an impact of tax cut policy on financial performances of the SMEs including family firms;

* There is no change in the cost of family firms as a result of a tax cut;

* The decreasing of the tax rate did not affect firm-specific indicators like Sales, and Net Income;

* Tax cut policy has an indirect effect on the SMEs, including family firms in the form of an increase in wages.

In general, the results propose that family business and financial performance relationships are complex, and they are possibly modified by factors not included in the analyses. Moreover, in a short time, the real effects of any tax policy may not be seen. However, it is better to define other indirect effects as well.

In this research, there are many unstudied aspects that could be contemplated in further studies. Future research can focus on developing a family business definition index that captures different levels of "familyness" by drawing inspiration and taking cues from methodological approaches already well established in this field of investigation. To measure performance, we used financial performance indicators such as ROA, ROE, NMP or Sales, and Net Income. In a future analysis, there also could be employed other different business dimensions such as employment, training, innovation and development. 


\section{References}

- Adams, R., Almeida, H., \& Ferreira, D. (2009). Understanding the relationship between founder-CEOs and firm performance. Journal of Empirical Finance, 16(1), 136-150. Crossref

- Anderson, R. C., Mansi, S. A., \& Reeb, D. M. (2003). Founding Family Ownership and the Agency Cost of Debt. Journal of Financial Economics, 68(2), 263-285. https://doi.org/http://www.sciencedirect.com/science/journal/0304405X Crossref

- $\quad$ Anderson, R. C., \& Reeb, D. M. (2003). Founding-Family Ownership and Firm Performance: Evidence from the S\&P 500. Journal of Finance, 58(3), 1301-1328. https://doi.org/10.1111/1540-6261.00567 Crossref

- $\quad$ Ang, J. S., Cole, R. A., \& Lin, J. W. (2000). Agency Costs and Ownership Structure. Journal of Finance, 55(1), 81-106. Retrieved from http://search.ebscohost.com/login.aspx?direct $=$ true $\& d b=b t h \& A N=2816931 \&$ site $=$ ehostlive Crossref

- Astrachan, J. H., Klein, S. B., \& Smyrnios, K. X. (2002). The F-PEC scale of family influence: A proposal for solving the family business definition problem1. Family Business Review, 15(1), 45-58. Crossref

- $\quad$ Beehr, T. A., Drexler Jr., J. A., \& Faulkner, S. (1997). Working in small family businesses: empirical comparisons to non-family businesses. Journal of Organizational Behavior, 18(3), 297-312. Retrieved from http://search.ebscohost.com/login.aspx?direct=true\&db=bth\&AN=12617388\&site=ehostlive Crossref

- Bouzgarrou, H., \& Navatte, P. (2013). Ownership structure and acquirers performance: Family vs. non-family firms. International Review of Financial Analysis, 27, 123-134. Crossref

- Calder, G. H. (1953). Some Management Problems of the Small Family-controlled Manufacturing Business. Indiana University.

- $\quad$ Che, L., \& Langli, J. C. (2015). Governance structure and firm performance in private family firms. Journal of Business Finance \& Accounting, 42(9-10), 1216-1250. Crossref

- Chrisman, J. J., Chua, J. H., \& Litz, R. (2003). A unified systems perspective of family firm performance: An extension and integration. Journal of Business Venturing, 18(4), 467472. Crossref

- Chrisman, J. J., Chua, J. H., \& Litz, R. A. (2004). Comparing the agency costs of family and non-family firms: Conceptual issues and exploratory evidence. Entrepreneurship Theory and Practice, 28(4), 335-354. Crossref

- Chrisman, J. J., Chua, J. H., \& Sharma, P. (2005). Trends and directions in the development of strategic management theory of the family firm. Entrepreneurship Theory and Practice, 29(5), 555-576. Crossref

- Chua, J. H., Chrisman, J. J., \& Sharma, P. (1999). Defining the Family Business by Behavior. Entrepreneurship: Theory \& Practice, 23(4), 19. Retrieved from http://search.ebscohost.com/login.aspx?direct $=$ true $\& d b=$ bth \&AN $=2553117 \&$ site $=$ ehostlive Crossref

- $\quad$ Claessens, S., Djankov, S., \& Lang, L. H. P. (2000). The separation of ownership and control in East Asian corporations. Journal of Financial Economics, 58(1), 81-112. Crossref

- Cucculelli, M., \& Micucci, G. (2008). Family succession and firm performance: Evidence from Italian family firms. Journal of Corporate Finance, 14(1), 17-31. Crossref

- De Massis, A., Kotlar, J., Campopiano, G., \& Cassia, L. (2015). The impact of family involvement on SMEs' performance: Theory and evidence. Journal of Small Business Management, 53(4), 924-948. Crossref

- $\quad$ Dyer, W. G. (2006). Examining the "family effect" on firm performance. Family Business Review, 19(4), 253-273. Crossref

- Faccio, M., Lang, L. H. P., \& Young, L. (2001). Dividends and expropriation. American 
Family Business and Financial Performance: What are the Effects of Tax Cut Policy on Them in Uzbekistan?

Economic Review, 54-78. Crossref

- Garcia-Castro, R., \& Aguilera, R. V. (2014). Family involvement in business and financial performance: A set-theoretic cross-national inquiry. Journal of Family Business Strategy, 5(1), 85-96. Crossref

- $\quad$ Gill, S., \& Kaur, P. (2015). Family Involvement in Business and Financial Performance: A Panel Data Analysis. Vikalpa: The Journal for Decision Makers, 40(4), 395-420. https://doi.org/10.1177/0256090915605756 Crossref

- Habbershon, T. G., \& Williams, M. L. (1999). A resource-based framework for assessing the strategic advantages of family firms. Family Business Review, 12(1), 1-25. Crossref

- Habbershon, T. G., Williams, M., \& MacMillan, I. C. (2003). A unified systems perspective of family firm performance. Journal of Business Venturing, 18(4), 451-465. Crossref

- Hamlyn, B. (1994). The quest for growth: a survey of UK private companies. Londres: Binder Hamlyn.

- Himmelberg, C. P., Hubbard, R. G., \& Palia, D. (1999). Understanding the determinants of managerial ownership and the link between ownership and performance. Journal of Financial Economics, 53(3), 353-384. Crossref

- Hulkar, T., \& Mirshod, T. (2016). The ways of development family business in the rural. International Scientific Review, (2 (12)).

- Litz, R. A. (1995). The family business: Toward definitional clarity. Family Business Review, 8(2), 71-81. Crossref

- Martínez, J. I., Stöhr, B. S., \& Quiroga, B. F. (2007). Family ownership and firm performance: Evidence from public companies in Chile. Family Business Review, 20(2), 8394. Crossref

- Miller, D. , \& Le Breton-Miller, I. (2006). Family Governance and Firm Performance: Agency, Stewardship, and Capabilities. Family Business Review, 19(1), 73-87. https://doi.org/10.1111/j.1741-6248.2006.00063.x Crossref

- $\quad$ Miller, D., Le Breton-Miller, I., Lester, R. H., \& Cannella, A. A. (2007). Are family firms superior performers? Journal of Corporate Finance, 13(5), 829-858. https://doi.org/10.1016/j.jcorpfin.2007.03.004 Crossref

- Rutherford, M. W., Kuratko, D. F., \& Holt, D. T. (2008). Examining the Link Between "Familiness" and Performance: Can the F-PEC Untangle the Family Business Theory Jungle? Entrepreneurship Theory and Practice, 32(6), 1089-1109. Crossref

- Saito, T. (2008). Family Firms and Firm Performance: Evidence from Japan. Journal of the Japanese and International Economies, 22(4), 620-646. https://doi.org/http://www.sciencedirect.com/science/journal/08891583 Crossref

- Sarvar, F. (2016). A unique approach to Family Business: Uzbekistan case. International Journal of Management Science and Business Administration, 2(10), 34-43. Crossref

- $\quad$ Singal, M., \& Singal, V. (2011). Concentrated ownership and firm performance: does family control matter? Strategic Entrepreneurship Journal, 5(4), 373-396. Crossref

- Villalonga, B., \& Amit, R. (2006). How do family ownership, control and management affect firm value? Journal of Financial Economics, 80(2), 385-417. Crossref

- Westhead, P., \& Cowling, M. (1997). The performance contrasts between family and nonfamily unquoted companies in the UK. International Journal of Entrepreneurial Behavior \& Research, 3(1), 30-52. Crossref

- Westhead, P., \& Cowling, M. (1998). Family Firm Research: The Need for a Methodological Rethink. Entrepreneurship: Theory \& Practice, 23(1), 31-56. Retrieved from http://search.ebscohost.com/login.aspx?direct $=$ true $\& d b=b$ th\&AN $=2033807 \&$ site $=$ ehostlive Crossref

- Wong, Y., Chang, S., \& Chen, L. (2010). Does a Family-controlled Firm Perform Better in Corporate Venturing? Corporate Governance: An International Review, 18(3), 175-192. Crossref

Zellweger, T. M., \& Astrachan, J. H. (2008). On the emotional value of owning a firm. Family Business Review, 21(4), 347-363. Crossref 